\title{
AN OVERVIEW OF SCIENCE EVALUATION IN POLAND AND CROATIA*
}

\author{
Patryk Ciurak ${ }^{* *}$ \\ Tea Mijač (*** $^{*}$ \\ Grzegorz Wierczyński****
}

Received: 29. 10. 2021

Professional paper
UDC 001.89:336](438:497.5)

Accepted: 25. 11. 2021

DOI https://doi.org/10.30924/mjcmi.26.2.13

\begin{abstract}
Science is considered to be the driving force of society and the economy; therefore, adequate evaluation and allocation of funds are necessary for achieving this. This paper briefly presents issues of the trends in the evaluation of scientific activities in Poland and Croatia. Based on the literature review, differences in the evaluation
\end{abstract}

Abstract

\section{INTRODUCTION}

Science is constantly being subjected to scrutiny. However, the intensity of evaluation has increased dramatically in recent decades, and the modes of evaluation have substantially changed (Wagner, 2018). The increased demand from policymakers for instruments to evaluate research at the institutional, national, and international levels has been noted (Sima, 2017). There are several ways in which science evaluation can be used; for example, it could be used systems of individual countries have been noted, as well as several recommendations.

Keywords: science evaluation, Polish science evaluation system, Croatian science evaluation system

for decisions regarding funding amount and assessing the performance of researchers, projects, institutions, etc. (Geuna \& Martin, 2003). Furthermore, one needs a priori to think through the conditions and purpose of evaluation (Wagner, 2018). For example, some countries use evaluation as a method of allocating funds and others as a management tool (Geuna \& Martin, 2003). To be more precise, the author within his paper makes a distinction between three primary research evaluation purposes: (1) to distribute public resources, (2) to improve the

* This paper is the output of the research project Social Science Research Policies and Evaluation, funded by the SEA-EU university alliance framework for support of collaborative research, administered by the University of Split, Croatia.

** Patryk Ciurak, MA, assistant, University of Gdansk, Faculty of Law and Administration, Department of Legal Informatics, Jana Bażyńskiego 6, 80-952 Gdańsk, Poland, Phone: +48 58523 29 76, E-mail: patryk.ciurak@ prawo.ug.edu.pl

*** Tea Mijač, PhD, assistant, University of Split, Faculty of Economics, Business and Tourism, Department of Business Informatics, Cvite Fiskovića 5, 21000 Split, Croatia, E-mail: tea.mijac@efst.hr

**** Grzegorz Wierczyński, D.Sc., associate professor, University of Gdansk, Faculty of Law and Administration, Department of Legal Informatics, Jana Bażyńskiego 6, 80-952 Gdańsk, Poland, Phone: +48 5852329 76, Email: grzegorz.wierczynski@prawo.ug.edu.pl 


\section{Journal of Contemporary Management Issues}

application of policies and programmes, and (3) to control the usage of public funds (Molas-Gallart, 2015).

For almost three decades, concerns regarding the rising costs of university-based research and the need to ensure value for money for public higher education investment have been growing (Geuna \& Martin, 2003). The premise is that funding distributed after the performance has been assessed will produce higher returns (Geuna \& Martin, 2003). Thus, countries all over the world have been working on their research evaluation systems (Lewandowska \& Kulczycki, 2021). Research evaluation policies differ across countries (Geuna \& Martin, 2003; Ochsner et al., 2020). The results indicate that two extremes can be identified - one is a pure performancebased, ex-post model, and another is the distribution of funds according to educational size (Geuna \& Martin, 2003).

A recent literature review focused on performance-based research evaluation arrangements since they are becoming the principal means for allocating research funds worldwide (Thomas et al., 2020) and global or country rankings (Gadd, 2019). In recent years, there has also been an increasing interest in establishing new research assessment methodologies beyond traditional citation-based measures (Knoth, 2016). There are several concerns regarding metrics being used. For example, when metrics focus on the number of citations, it does not directly measure the research result's quality. According to the authors, at best, it refers to other scholars' perceptions and awareness of it, and even this measure is debatable (Wagner, 2018). Also, one of the common issues relevant to social sciences and humanities is the Web of Science (WoS) coverage since it does not illustrate the total units' production (van den
Besselaar \& Sandström, 2020). The results point out that WoS does not cover some international publications.

However, countries confront a barrier in incorporating practice-based academic subjects into assessment frameworks. Evaluation systems also pose different challenges depending on the research field under evaluation (Molas-Gallart, 2015). For example, a recent paper explains how Poland has tackled the difficulty of research assessment in art and how it affects research productivity within the Polish system (Lewandowska \& Kulczycki, 2021). As the authors state, the Polish research evaluation model is significantly different from other country models.

While the literature review indicates how studies should be conducted at the system level and how global study fields are affected rather than just specific studies in local settings (Thomas et al., 2020), another study also highlights that evaluation procedures must reflect the needs of the research in the country, its research policy as well as the academic structure in the country (Ochsner et al., 2020). This paper describes the design of both the Croatian and Polish systems of research evaluation.

\section{SCIENCE EVALUATION IN CROATIA}

Scientific organizations in Croatia refer to (Agency for Science and Higher Education of the Republic of Croatia, 2021): (1) 25 public scientific institutes, (2) higher education institutions, namely 8 public universities, 72 constituent units of public universities (faculties, academies, and university departments), 6 colleges and 4 public polytechnics, and (3) legal entities outside the system of higher education and 
public scientific institutes that registered scientific activity.

In Croatia, public scientific organizations receive funding from the general budget, which relies primarily on public funding from the state budget ${ }^{1}$. The way the money is distributed is considered "traditional" - this type of funding is called primary funding. Primary funding is awarded to all public higher education institutions, and the amount that can be paid for scientific and teaching activities depends on the data provided by higher education institutions. There are two types of primary funding (Government of the Republic of Croatia, 2018). Primary funding for teaching activities is based on the amount of full subsidy for participation in the costs of studies of an individual student, depending on the type of study programme and scientific or artistic field, and based on the number of students eligible for participation in study costs. For university studies, the amount per student in the social sciences and humanities is HRK 4,300.00, in the STEM field HRK 6,000.00, while for a student in the arts, the amount is HRK 7,500.00. Primary funding for scientific and artistic activities is calculated based on the following formula:

- STEM fields: [(number of WoS publications / total number of employed scientists and artists selected for a fulltime scientific or artistic title in STEM area) * HRK $13,500.00 *$ number of employed scientists and artists elected to the full-time scientific or artistic title in the STEM field at the expense of the state budget].

- Social sciences and humanities: [(number of papers in WoS or SCOPUS) / total number of employed scientists

\footnotetext{
Act on Scientific Activity and Higher Education https://www.zakon.hr/z/320/Zakon-o-znanstvenoj-djelatnosti-i-visokom-obrazovanju
}

elected to a full-time scientific or artistic title (FTE) in the SocSci/Hum. area) * HRK $7,500.00 *$ a number of employed sci-entists and artists selected for a full-time scientific or artistic title (FTE) in the SocSci/Hum. area at the expense of the state budget].

Besides the primary funding, in 2008, the idea of performance-based funding was initiated, resulting in the so-called programme contracts. During 2010 and 2011, in cooperation with the World Bank and public universities, the Ministry of Science and Education began developing the concept of programme contracts. In 2012, in agreement with the Ministry of Finance, they created financial preconditions for signing three-year contracts with higher education institutions. In addition to financial resources, the intention was to define the development goals of public higher education institutions and indicators that would monitor their achievement. The goals of programme contracts are (Ministry of Science and Education of the Republic of Croatia, 2019):

- Relevance to current and future needs of the labour market and development of the economy and society, efficiency and internationalization of higher education

- The excellence of scientific and artistic work

- Science, art, and higher education as drivers of change in society and the economy.

In 2018, a structural change of funding was initiated with the ultimate goal of establishing comprehensive funding for higher education and science, based on achieving results and strategic goals founded on the principles of transparency, efficiency, quality assurance, and social dimension in 


\section{Journal of Contemporary Management Issues}

higher education. In 2018, the Government of the Republic of Croatia adopted a Decision on the programme financing of public higher education institutions in the Republic of Croatia in the academic years 2018/2019, 2019/2020, 2020/2021, and 2021/2022) (Government of Croatia, 2018). The programme contract states clear goals and indicators for teaching, research, and the specific profile of the institution. The aforementioned primary funding is envisaged, as well as additional funding based on results.

Higher education institutions that agree to sign programme contracts will also be provided with funding for activities to achieve specific institutional objectives that are monitored according to the following indicators:

- Compliance of study programmes with the qualification standards from the Register of the Croatian Qualifications Framework

- Employment-based on the results of employment monitoring - share of students who completed their studies in $n$ +1 time of nominal duration of studies (n)

- Share of incoming foreign professors/ scientists (FTE) (incoming mobility of scientists)

- Share of incoming international students (incoming student mobility)

- Increase the number of scientific books with international review

- Increase in the number of accepted patents

- Increase the share of graduate students who are the first generation in the family in higher education in the total number of graduates.
Currently, not all scientific units have signed the contract. However, within the recent conference briefing, the Minister stated that the reform of higher education and scientific system is manifested in improving the financing model through the introduction of complete programme contracting, which is expressed as one of the following goals ${ }^{2}$.

\section{SCIENCE EVALUATION IN POLAND}

The beginnings of a systemic evaluation of scientific units in Poland are connected with the establishment of the State Committee for Scientific Research (Polish: Komitet Badań Naukowych - KBN). Its main task was to distribute funds for scientific research - both state subsidies for universities and grants for individual researchers.

From the very beginning of its activity, the Committee evaluated scientific units within particular scientific disciplines to determine the number of subsidies for scientific research. The Committee had panels representing several scientific disciplines (e.g. the Panel for Social Sciences, Economics, and Law). The panels were appointed for a four-year term, hence the tradition that the scientific units are evaluated once every four years. Each panel established detailed evaluation criteria, such as definitions of terms used, number of points awarded for specific results, and requirements for documentation necessary for the evaluation of entities. This made it possible to take into account the particular nature of individual scientific disciplines. The process itself was

Conference conclusions (2021). Available at: https:// www.srednja.hr/faks/ministar-fuchs-na-nasoj-konferenciji-ukratko-predstavio-reformu-visokog-obrazovanja-i-znanosti/ (accessed November 23, 2021) 
Management, Vol. 26, 2021, No. 2, pp. 229-244

P. Ciurak, T. Mijač, G. Wierczyński: AN OVERVIEW OF SCIENCE EVALUATION IN ...

non-transparent and unaccountable, but the number of public subsidies for research was so negligible that the decisions of the Committee were not questioned. Over time, more and more financial streams depended on the scientific category obtained, and therefore the evaluation process became more and more formalised.

In 2004, the Committee was incorporated into the structure of the Ministry of Science, while in 2010, two large state agencies - the National Science Centre and the National Centre for Research and Development - took over the grant awarding. Throughout this period, evaluation was and is treated as an auxiliary tool in awarding state grants and is, therefore, carried out by the Ministry of Science. Evaluation is performed by a specially established Commission for the Evaluation of Science (Polish: Komisja Ewaluacji Nauki, formerly called the Commission for the Evaluation of Scientific Units, Polish: Komisja Ewaluacji Jednostek Naukowych). The evaluation results were not and are not significant in grant awarding procedures and are, therefore, not used or elaborated by Polish public grant agencies.

The result of the evaluation were scientific categories awarded for several years. Initially, these categories were defined by numbers (from 1 to 5, with category 1 being the highest), and since 2010 - by letters $(\mathrm{A}+, \mathrm{A}, \mathrm{B}, \mathrm{C}$, where $\mathrm{A}+$ means "leading level", A - "very good level", B - "satisfactory level" and C - "unsatisfactory level").

The last evaluation was conducted in spring 2017 and covered the period from 2013 to 2016. The evaluation scheduled for spring 2021 did not take place due to the pandemic. It is scheduled to take place in spring 2022 and cover the period from 2017 to 2021 . The remainder of this paper will discuss the principles and results of the
2017 evaluation and the planned principles for the evaluation to be conducted in 2022 .

\subsection{Evaluation of scientific units in 2017}

The evaluation of scientific units in 2017 was conducted according to almost the same criteria as the previous evaluation in 2013. The criteria were established in the Regulation of the Minister of Science and Higher Education of 12 December 2016 on granting scientific category to scientific units and universities in which, according to their statutes, basic organisational units have not been separated ${ }^{3}$.

The evaluation was conducted by the Committee for Evaluation of Scientific Units (Polish: Komitet Ewaluacji Jednostek Naukowych, KEJN), based on information on the effects of scientific as well as research and development activities presented by scientific units in questionnaires submitted in electronic form in a specially designed IT system. The evaluation was obligatory for public scientific units (universities and research units) while for scientific units at private universities only voluntarily. Since universities are dominated by employees who, in addition to their scientific duties, also have teaching responsibilities, university units were evaluated in comparison with each other, while research units were evaluated separately.

The evaluated entities were scientific units, i.e., formally separated parts of universities or research units (e.g., faculties or institutes). Scientific units were evaluated in the so-called joint assessment groups, which generally correspond to the division into scientific disciplines. Scientific units that employed researchers representing various scientific disciplines (the so-called heterogeneous units) could submit applications

3 Official Journal of the Republic of Poland of 2016, item: 2154. 


\section{Journal of Contemporary Management Issues}

for evaluation in several groups of common evaluation, but only in such to which more than $35 \%$ of the employees of a given unit were assigned. The principle that formally understood scientific units are subject to evaluation was a source of much controversy in practice. In practice, many scientific units employed scientists who did not represent the leading scientific discipline in a given unit. Taking into account the works of such scientists in the evaluation in a given joint assessment group raised doubts. For example, the Faculty of Law and Administration of the Jagiellonian University submitted papers on the composition of concrete in the ancient Roman Empire because it employed one scientist conducting research on this subject. This was questioned by the team evaluating law faculties, but after an appeal, the Committee for the Evaluation of Scientific Units recognised that the Faculty of Law and Administration of the Jagiellonian University was entitled to submit this work. This was important insofar as the works were published in non-legal journals, which had much higher scores than legal journals. As a result, the Faculty of Law and Administration of the Jagiellonian University obtained a higher scientific category $(\mathrm{A}+$ instead of the initially obtained $\mathrm{A})$. Such cases resulted in establishing the rule stating that (while planning the next evaluation) within a given group, only employees and publications ascribed to a given scientific discipline may be taken into account (problems this raises will be discussed in the following sections of this paper).

As part of the evaluation, individual teams awarded points to scientific units for achievements in four criteria:

1. scientific achievements;

2. scientific potential;

3. practical effects of scientific activity;

4. other scientific outputs.
Scientific achievements were understood as scientific publications, both in the form of articles published in scientific journals or books and chapters in books ${ }^{4}$. In sciences, this category also included patents and inventions. The upper limit for publications submitted by a scientific unit was three times the number of employees in a given unit and there were no restrictions as to whose publications were submitted by a given unit. It was, therefore, possible for a given unit to submit a dozen or even several dozen publications by one of its employees and at the same time no publications by another employee. TH points for books and chapters in books were uniform, whereas the points for articles in journals were differentiated, specified in a list of journals drawn up by the Ministry for evaluation purposes. Subsequent editions of this list have been published since the late 1990s, initially by the Committee for Scientific Research and since 2004 by the Ministry of Science. The list issued in early $2017^{5}$ was divided into three parts A, B, and C. Part A determined the number of points for publications in scientific journals with an Impact Factor (IF) included in the Journal Citation Reports (JCR) database; Part B determined the number of points for publications in scientific journals without an Impact Factor (IF), and Part $\mathrm{C}$ determined the number of points for publications in scientific journals included in the European Reference

\footnotetext{
Different fields of science allowed different percentages of books and chapters - for social sciences and humanities it was a maximum of $40 \%$ of submitted publications, for science and engineering - $20 \%$, and for life sciences - $10 \%$

5 All previous ministerial lists of scientific journals were retroactive. The lists were usually published at the end of the year and applied to reports for the time preceding their publication. This meant that scientists found out only after the publication of a given article how many points it would receive in the scientific evaluation process. This was (and is) a clear violation of the lex retro non agit principle.
} 
Index for the Humanities (ERIH) database. Parts $\mathrm{A}$ and $\mathrm{C}$ were created based on the abovementioned databases, while Part B was created based on requests from interested journal editors. The scores adopted in this list were based on the assumption that journals not indexed in the Journal Citation Reports database are of much lower quality than journals indexed in this database. Part A journals were assigned $15-45$ points, Part C journals 10-20 points, and Part B journals $1-15$ points. Since only journals in the sciences and medicine are overwhelmingly represented in JCR, the adoption of such an allocation policy resulted in de facto discrimination against the social sciences and humanities. The representatives of these sciences did not duly protest this as the evaluation was carried out by comparing units covering the same scientific disciplines and there seemed to be no serious consequences of this discrimination.

The term scientific potential in the social sciences and humanities was primarily understood as authorisations to confer doctoral and postdoctoral degrees and professorial titles obtained in the unit. To a lesser extent, this criterion also took into account the mobility of unit employees, including their research, stays in other research centres, membership of unit employees in the governing bodies of foreign or international scientific societies, organisations, and institutions, performing by unit employees the function of editors-in-chief of scientific journals included in Part A of the list of scientific journals and publishing a scientific journal included in Part A or Part C of the list. In the sciences, this category also included having accredited laboratories.

The term practical effects of scientific achievements were understood as financial resources obtained by the unit for scientific projects and financial resources obtained as a result of the commercialisation of research results.

The last category - "other effects of scientific activity" was an expert category in which ten "most important achievements of the unit of scientific, economic, and social significance" were evaluated.

The weights of the individual criteria were different for each field of science. For all units, the criterion scientific achievements had a weight of 65 . For units representing the social sciences and humanities, scientific potential and other effects of scientific activity had a weight of 15 , and the least weight was practical effects of scientific activity - 5 . For units representing science, engineering, and life sciences, practical effects of scientific activity had a weight of 15 , and scientific potential and other effects of scientific activity had a weight of 10 .

The number of points obtained in each category was then divided by the number of scientific and didactic staff. The scores obtained in this way were compared with reference values for category $\mathrm{A}$ and category B, established by the Committee for Evaluation of Scientific Units and approved by the Minister. On this basis, scientific units were given scientific categories A, B, or C. Subsequently, an additional expert assessment of scientific units distinguished by the quality of their research was carried out, and on its basis, the best entities with category A were awarded category A+.

The 2017 evaluation assessed 993 research units (including 781 university units). Category A+ was achieved by 47 units, category A by 332 units, category B by 467 units, and category C by 147 units (Ministry of Science and Higher Education of Republic of Poland, 2017). 


\section{Journal of Contemporary Management Issues}

The literature summarizing the 2017 evaluation noted, among other things, that:

1) the enormous amount of effort and time that went into conducting this evaluation is disproportionate to achieving the goal of distributing relatively small public research grants,

2) the whole process was not transparent enough,

3) huge amounts of data have been collected - again - that have not been used to create a public database of scientific publications,

4) the assumption that formally understood organisational units of a university are subject to assessment does not allow for proper consideration of the specific nature of particular scientific disciplines (as in the case of universities, due to teaching needs, many faculties employ scientists representing a different discipline of science),

5) there were too many parameters to be evaluated,

6) adopting the fact that a scientific unit is subject to evaluation without indicating upper and lower limits for publications submitted by its individual employees resulted in the evaluation mainly of a small group of leaders of a given unit and, at the same time, does not motivate other scientists employed in this unit to work,

7) there was no social impact assessment,

8) the scoring system for publications (both for journal articles and books) needs to be improved (Kulczycki, 2019).

\subsection{Principles of evaluation planned for 2022}

In July 2018, a new Act: "Law on Higher Education and Science" was enacted $^{6}$. It represented a thorough reform of the system of science and higher education. One of the areas that underwent deep reconstruction was the system of evaluation of scientific units. Not only the rules of carrying out the evaluation but also its purpose was changed.

Regarding the purpose of evaluation, there are two things to emphasise. First, the 2018 Act reformed the way financial streams are directed to universities, making them much more dependent on the results of the evaluation. The Act introduced the concept of research universities, which were to receive much higher subsidies for research. The status of such a university may be obtained only by such universities in which at least half of the scientific units have scientific category A+ or A. Secondly, the Act significantly expanded the importance of evaluation results, as it made the rights to confer doctoral and postdoctoral degrees dependent on them. Until now, the entitlements to the doctoral and postdoctoral degrees were not conditional on having a specific scientific category but only on having the required number of employees specialising in each discipline of science. According to the new rules, these rights are to be granted only to those units that have $\mathrm{A}+, \mathrm{A}$, or $\mathrm{B}+$ in each discipline of science. The adoption of such a rule automatically meant that the possession of these rights ceased to function as an evaluation criterion.

\footnotetext{
6 Act of 20 July 2018. - Law on Higher Education and Science (unified text: Official Journal of the Republic of Poland of 2021, item 478 as amended).
} 
At the same time, significant changes were introduced to the rules of conducting evaluations.

The first change consists in abandoning the principle that the organisational units of a university are subject to evaluation. It has been replaced with the rule that all researchers employed at a given university who have declared belonging to this discipline are subject to evaluation in each discipline. Thus, if a law researcher is employed at a faculty other than the faculty of law, then during the evaluation process, he/ she will be counted among the employees representing legal sciences and not among the faculty employees at which he/she is employed. With this change, the rule that scientific journals are assigned to scientific disciplines has also been introduced, and in the evaluation process in each discipline, only articles published in journals assigned to that discipline can be submitted. The lists of journals published by the Ministry of Science in 2019 and 2021 have shown that the process of qualifying journals for particular scientific disciplines raises many difficulties in practice.

The second important change is the introduction of the maximum limit of publications submitted in the evaluation process for individual employees of the scientific unit (researcher limit). The overall publication limit has not changed (it is still three times the number of employees), but at the same time, only four publications ${ }^{7}$ of a particular employee can be submitted. This solution caused that the result of the evaluation will be more influenced by a group of employees who publish few scientific

7 This is a certain simplification. In the case of multiauthor publications, the share of a given author is reported in the evaluation. The sum of these shares cannot exceed the equivalent of 4 single-author publications. works and less than before influenced by the leaders of the given unit.

Changes have also been introduced in the scoring of scientific publications. Apart from the list of journals, a list of publishing houses that issue reviewed scientific monographs has been introduced. It has been divided into two levels - the second level, with much higher scoring, are publications "making a significant contribution to the development of world science." The list announced in September 2020 contained 692 publishers at level I and 36 publishers at level $\mathrm{II}^{8}$. There is a fundamental score difference between these levels - monographs published in level I publishing houses receive 80 points (in the social sciences and humanities - 100), while chapters in such monographs receive 20 points. Monographs published in level II publishing houses are awarded 200 points (300 in the social sciences and humanities), while chapters in such monographs are awarded 50 points (75 in the social sciences and humanities).

The official list of journals has also undergone fundamental changes. Firstly, it has been assumed that the condition of including a journal in the list is its indexation in specific databases. To these, the Ministry of Science has included only:

1) Scopus,

2) Four databases belonging to $W e b$ of Science: Science Citation Index Expanded, Social Sciences Citation Index, Arts \& Humanities Citation Index, Emerging Sources Citation Index (hereinafter collectively referred to as Web of Science databases),

8 See the announcement of the Minister of Science and Higher Education of 29 September 2020 on the list of publishers publishing peer-reviewed scientific monographs, https://www.gov.pl/attachment/033fle63-ab794c4b-9c27-d3848d845033, accessed 15.10.2021. 


\section{Journal of Contemporary Management Issues}

3) European Reference Index for the Humanities and Social Sciences $(\mathrm{ERIH}+)$.

The scoring scale differs significantly from previous ones - 6 levels of scoring were set - 20, 40, 70, 100, 140, and 200 points. The entire evaluation process was divided into two stages. In the first bibliometric stage, journals indexed in Scopus or Web of Science databases could gain from 20 to 200 points (this depended on the citation indexes in these databases), whereas journals indexed only in the ERIH+ database gained a minimum of 20 points. In the second stage, teams of experts from individual scientific disciplines could change the score resulting from the first stage by up to two levels. Under the applicable regulations, both stages were conducted by the Commission for the Evaluation of Science.

As one can easily see, such a solution has further exacerbated the actual discrimination against the social sciences and humanities, since journals from these sciences are represented to a much smaller degree in the Scopus or Web of Science databases than journals from the natural sciences and medical sciences.

All the changes discussed above have significantly increased the importance of evaluation results. The closer we get to the deadline for evaluation, the greater the pressure to change its principles or soften its effects. These pressures began to have an effect when the previous Minister, who had initiated the reform, was forced to resign in 2020.

On 29 September 2020, the Minister of Science and Higher Education published a new list of publishing houses that issue peer-reviewed scientific monographs. The new list includes entities that did not obtain a positive recommendation of the Commission for the Evaluation of Science, as required by the existing regulations. with The scientific committees of the Polish Academy of Sciences, which is also required by the regulations in force in Poland were also not consulted about the changes in the list. The Committee of Legal Sciences of the Polish Academy of Sciences protested against such a procedure ${ }^{9}$, but it did not provoke any reaction.

Even more drastic violations of the law occurred in the case of the journals list. On 9 February 2021, the Ministry of Science published a new list of scientific journals ${ }^{10}$. Two days later, the Commission for the Evaluation of Science issued a statement in which it informed that it "was surprised by the publication of the list of scientific journals," as it contains "items that the Commission did not proceed and did not recommend ${ }^{11}$." The Commission stated that it had prepared a draft of the list, taking into account the journals included in the international databases indicated in the Regulation, but that the version published by the Minister "included 73 journals which had not been considered or recommended by the Committee for Scientific Research" and "in the case of 237 journals, there were increased scores, which had not been

\footnotetext{
9 Resolution No. 9/2020 of the Committee of Legal Sciences of the Polish Academy of Sciences of 15 October 2020 on reprehensible practices when drawing up the list of scientific publishing houses, https://knp.pan.pl/index.php?option=com_content\& view $=$ article\&id=209:uchwala-nr-9-2020-komitetunauk-prawnych-pan-z-dnia-15-pazdziernika-2020r\&catid=68\&Itemid=166, accessed 15.10.2021

10 The announcement was published at: https://www. gov.pl/web/edukacja-i-nauka/nowy-rozszerzonywykaz-czasopism-naukowych-i-recenzowanychmaterialow-z-konferencji-miedzynarodowych, accessed 22.02.2021.

11 The statement of the Commission for the Evaluation of Science of 11 February 2021 was published at https://forumakademickie.pl/sprawy-nauki/komunikatkomisji-ewaluacji-nauki/, accessed 22.02.2021.
} 
consulted with the Committee for Scientific Research either". The Commission stressed that "in no available source could it find substantive justification for the introduced changes."

Among the journals which were included in the list or whose scoring was increased without the required procedure and contrary to the binding substantive rules, journals from the area of social sciences and humanities dominated, including a relatively numerous group of law journals. Therefore, one of the first bodies to react to the described events was the Committee of Legal Sciences of the Polish Academy of Sciences. In resolution no. 1/2021 of 15 February $2021^{12}$ The Committee strongly protested "both the manner in which the referenced list was compiled, as well as its content." The Committee stressed that "a decisive act of the Minister cannot be an arbitrary action, contrary to the law" and assessed that the journals referred to in the statement of the Committee for the Evaluation of Science" were added to the indicated list or the scoring of the journals was increased, in a non-transparent manner, with the intention to valorise certain circles and, first of all, contrary to the rules of determining the scoring resulting from the regulation referred to."

On the same day, the Committee on Psychological Sciences of the Polish Academy of Sciences also protested ${ }^{13}$.

\footnotetext{
12 The resolution was published at: http://www.knp.pan. $\mathrm{pl} /$ index.php?option $=$ com_content $\& v i e w=$ article $\&$ id =216:uchwala-nr-01-2021-komitetu-nauk-prawnychpolskiej-akademii-nauk-z-dnia-15-lutego-2021-rokudot-wykazu-i-punktacji-czasopism-naukowychi-recenzowanych-materialow-z-konferencjimiedzynarodowych \&catid $=69 \&$ Itemid $=167$, accessed 22.02.2021.

13 This opinion was published at: http://www.kompsych.pan.pl/images/Uchwa\%C5\%82y/Stanowisko_KP_PAN_ws_zmiany_punktacji_czasopism_ naukowych.pdf, accessed 27.02.2021.
}

The Committee stressed that "the way in which the list has been created - bypassing the Committee for the Evaluation of Science - is a serious violation of the Act of 20 July 2018 Law on Higher Education and Science and the Regulation of the Ministry of Science and Higher Education of 7 November 2018 (...)", "updating the scoring of selected journals is not based on objective criteria and is non-transparent, while the existing scoring, developed by the Commission for the Evaluation of Science and consulted with experts from all fields of science, resulted from reliable bibliometric indicators", "increasing the scoring of Polish-language regional journals with a short history and low reputation will motivate many academics to publish research results outside the circulation of world science", "in this way the prestige of Polish science is not increased, rather it is method for marginalisation", "including in the list purely journalistic periodicals, which do not have appropriate procedures for independent reviews, blurs the important distinction between scientific writing and journalism", which "leads to the downfall of the authority of science and the loss of its unique status" and that "increasing the scoring of a number of journals associated with specific scientific centres and selected disciplines leads to a conflict in the scientific community and puts some editors and universities in an ambiguous situation".

An equally strong statement was issued by the Committee on Ethics in Science of the Polish Academy of Sciences. In opinion no. 2/2021 of 16 February $2021^{14}$ the Committee concluded, among others, that the manner of introducing the changes to the list was not only unlawful, but also was "an unprecedented violation of the ethical principles of

\footnotetext{
14 The opinion was published at: http://www.ken.pan. pl/images/KEN_stanowisko_2_2021.pdf, accessed February 22, 2021.
} 


\section{Journal of Contemporary Management Issues}

impartial and fair evaluation, which will result in a decrease in confidence in science, a lowering of the level of scientific research in the country, as well as unfavourable perception of Polish science on the international arena". The Committee also pointed out, among others, that "arbitrary changes in the list cancel out the efforts of thousands of Polish scientists to obtain the best results, suggesting that their scientific career is determined not by real scientific achievements, but by fulfilling the ideologically motivated expectations of those in charge". The Committee assessed that the procedure of introducing changes to the list "undermines the reputation of scientific units publishing journals which have been added to the list without substantial justification or whose scores have been increased in this way", "may be the basis for questioning or challenging the results of the evaluation of scientific units, which constitutes, among others, the basis for the distribution of funds allocated for the financing of science" and "contradicts the principles of equal treatment of and respect for scientist".

On 18 February, the Academy of Young Scholars of the Polish Academy of Sciences ${ }^{15}$ protested. It was stated, among others, that "this discretionary interference is in our opinion an expression of disregard for the results of work of several expert teams, which developed the list in force so far, the recommendations of the Commission for the Evaluation of Science, as well as the voice of many academic institutions and scientists, whose activity directly depends on the transparency and stability of the evaluation criteria. It undermines trust in the evaluation process, on which the policy of quality and financing of research is based, which may have grave consequences in the near future.

15 The opinion was published at: https://amu.pan.pl/ amu-pan-sprzeciwia-sie-arbitralnym-zmianom-wwykazie-czasopism, accessed February 27, 2021.
The manner in which the changes have been made also raises legal concerns. The modifications made to the list do not, in most cases, reflect the scientific level or importance of journals, but instead, blur the line between excellent and mediocre journals and promote journalism at the expense of scientific work."

Despite such strong reactions from the academic community, the Minister of Education and Science issued another announcement on 18 February 2021 "on the amendment and correction" of the announcement of 9 February $^{16}$, in which five new scientific journals were added to the list and increased scoring in case of 96 scientific journals. On 22 February 2021, the Commission for the Evaluation of Science published an announcement stating that it "did not participate in the elaboration" of the changes introduced by the Minister's announcement of 18 February $2021^{17}$. As a result, the abovementioned scientific committees of the Polish Academy of Sciences (PAS) expressing their objection to the way the list of journals was established were joined by, among others: the Conference of Rectors of Academic Schools in Poland ${ }^{18}$, the Committee on Philosophical Sciences PAS $^{19}$, the

16 The announcement was published at: https://www. gov.pl/web/edukacja-i-nauka/zmiana-i-sprostowaniekomunikatu-ministra-edukacji-i-nauki-z-dnia-9-lutego-2021-r-w-sprawie-wykazu-czasopism-naukowych-i-recenzowanych-materialow-z-konferencjimiedzynarodowych (accessed February 22, 2021).

17 The announcement of The Commission for the Evaluation of Science No. 2/2021 of 22 February 2021 was published at https://forumakademickie.pl/ sprawy-nauki/komunikat-komisji-ewaluacji-nauki, accessed February 27, 2021.

18 The opinion of the Presidium of the Conference of Rectors of Academic Schools in Poland of 22 February 2021 was published at https://www.krasp.org. $\mathrm{pl} /$ resources/upload/dokumenty/Uchwa\%C5\%82y/ kadencja\%202020-2024/dok_9VIII-wykaz_czasopism_naukowych.pdf, accessed March 12, 2021.

19The opposition was published at https://knf.pan.pl/, accessed: February 27, 2021 
Committee of Cultural Studies PAS $^{20}$, the Committee on Demographic Sciences PAS ${ }^{21}$, the Committee on Literary Studies PAS $^{22}$, the Committee on Political Sciences PAS ${ }^{23}$, the Committee on Oriental Studies $\mathrm{PAS}^{24}$, the Main Council of Science and Higher Education $^{25}$, the Committee of Linguistics $\mathrm{PAS}^{26}$, the Committee on Sociology $\mathrm{PAS}^{27}$,

20 The support was published at http://www.knok.pan. pl/index.php/apele-i-stanowiska, accessed: March 12, 2021.

21 Resolution No. 2/2021 of the Committee on Demographic Sciences of the Polish Academy of Sciences of 22 February 2021 published at http://knd.pan.pl/images/Uchwa\%C5\%82a_2_2021.pdf, accessed March $12,2021$.

22 Opinion of The Committee on Literary Studies of the Polish Academy of Sciences of 23 February 2021 published at http://www.knp.pan.pl/ index.php?option $=$ com_content $\&$ view $=$ article \&id=219: stanowisko-nauk-o-literaturze-pan-z23-02-2021-r-dla-uchwaly-komitetu-nauk-prawnychw-sprawie-wykazu-i-punktacji-czasopismnaukowych\&catid=67\&Itemid=164, accessed March 19, 2021.

23 Opinion of the Political Science Committee of the Polish Academy of Sciences of 23 February 2021, http://www.knpol.pan.pl/images/KNP_News/ Stanowisko_nr_1-II-2021.pdf, accessed March 12, 2021.

24 Support for the resolution of the Committee of Legal Sciences of the Polish Academy of Sciences of 23 February 2021, published at http://kno.pan.pl/images/Poparcie_KNO_dla_Uchwa\%C5\%82y_KNP PAN.pdf, accessed March 12, 2021.

25 Opinion No. 30/2021 of the General Council for Science and Higher Education of 26 February 2021, published at https://rgnisw.nauka.gov.pl/2021/02/26/ stanowisko-nr-30-2021-rady-glownej-nauki-i-szkolnictwa-wyzszego-z-dnia-26-lutego-2021-r-wsprawie-najnowszego-wykazu-czasopism/, accessed October 19, 2021.

26 Resolution No. 2/2021 of the Committee of Linguistics of the Polish Academy of Sciences of 1 March 2021, unpublished.

27Opinion of the Committee on Sociology, Polish Academy of Sciences of 1 March 2021, published at http://www.knp.pan.pl/images/Stanowsko_Komitetu_Socjologii_PAN_w_sprawie_listy_czasopism. png, accessed March 12, 2021). the Slavic Studies Committee PAS ${ }^{28}$, the Art Sciences Committee PAS ${ }^{29}$, the Board of the Polish National Historical Committee PAS ${ }^{30}$, the Committee of Pedagogical Sciences $\mathrm{PAS}^{31}$, the Statistics and Econometrics Committee PAS $^{32}$ and the Polish Academy of Arts and Sciences ${ }^{33}$. These were scientific committees representing mainly the social sciences and the humanities. The committees representing the natural sciences, engineering, and medicine did not protest, as the infringements of the law during the publication of the new list hardly affected journals from these fields of science.

28 Resolution No. 1/2021 of 4 March 2021 of the Slavic Studies Committee, Polish Academy of Sciences, published at http://komslow.pan.pl/images/Uchwala_nr_1_2021.pdf, accessed March 12, 2021.

29Resolution No. 2/2021 of 4 March 2021 of Art Sciences Committee, Polish Academy of Sciences, published at http://www.knos.pan.pl/, accessed March 19,2021

30 Resolution No. 1/2021 of 11 March 2021 of the Board of the Polish National Historical Committee, Polish Academy of Sciences, published at http:// www.knp.pan.pl/images/KNH_Uchwaa_Prezydium_nr_1-2021.png, accessed March 19, 2021.

31 Opinion of the Committee of Pedagogical Sciences, Polish Academy of Sciences published at http://www. knped.pan.pl/index.php?option=com_content\&view $=$ article \&id=397: position-position-of-the-committeeof-pedagogical sciences-pan-on-publication-byministry-of-education-and-science-new-expandedlist-of-scientific-journals-and-recorded-materialsfrom-international-conferences-published-on-19-Feb2021-year\&catid $=47 \&$ Itemid $=182$ (accessed March $16,2021)$.

32 Resolution No. 2/2021 of 19 March 2021 of the Statistics and Econometrics Committee of the Polish Academy of Sciences, unpublished.

33 Resolution of 23 March 2021 of the Polish Academy of Arts and Sciences Council, unpublished. 


\section{Journal of Contemporary Management Issues}

\section{CONCLUSIONS}

The described events of 2019-2021 lead to the following conclusions:

- A far-reaching reform of the evaluation of scientific units requires ensuring long-term support from public institutions. Such a support in Poland broke down shortly after the reform came into force, and many unauthorized changes have been introduced, which makes the results of the evaluation planned for 2022 questionable from the legal point of view.

- Making the evaluation based on databases that unequally represent journals from particular fields of science delegitimises the evaluation process in the eyes of the representatives of these fields. As long as Scopus and Web of Science databases represent different fields of science to different degrees, the evaluation of scientific entities cannot be limited to the data contained in these databases.

- The adopted methods of counting points for publications in journals are beneficial, especially for social sciences and humanities (Korytkowski \& Kulczycki, 2019). However, for these benefits to be effective, the journals need to be included in the databases considered for evaluation. Before the changes in the lists of scientific journals, there was considerable pressure on publishing houses to start making efforts to be recognized by the databases. Introducing the changes, however, will make it virtually impossible to assess whether the evaluation will bring the intended effect.

- It is difficult to negate the view that the introduced researcher limit will motivate all those obliged to publish scientific papers, as well as the fact that it may negatively affect top-performing researchers (Korytkowski \& Kulczycki, 2019). At the same time, it may encourage to calculate how many publications and in which journals are sufficient to achieve the number required for the evaluation. After reaching this number, the motivation for further research may simply cease. At the moment, it is difficult to assess whether the overall effect of this approach will be positive (more of better publications from researchers as a whole) or negative (fewer outstanding publications from top-performing researchers).

- Creating an excellence-based research funding system assumes that only outstanding and ground-breaking achievements are valued (Kulczycki et al., 2017). Meanwhile, achievements of lesser rank, but still conducted using proper scientific methods, should also be published to lay the groundwork for making a breakthrough discovery. This will not happen until a 'critical mass' is reached when someone will be able to 'connect the dots' coming from the basic research. Another consequence may be a reluctance to publish partial research results before a breakthrough discovery has been announced, thereby limiting access to them.

- Focusing during the evaluation process only on the most important, most appreciated achievements is undoubtedly justified if one aims to create an evaluation system based on scientific excellence. It can also have a motivating effect on researchers to seek opportunities to join high-performing scientific teams or consortia. However, potential dangers of this approach should not be overlooked. Besides selfcitation groups and fake collaborations 
Management, Vol. 26, 2021, No. 2, pp. 229-244

P. Ciurak, T. Mijač, G. Wierczyński: AN OVERVIEW OF SCIENCE EVALUATION IN ...

(Kulczycki et al., 2017), there is also a chance for a narrowing of the views presented in science. Making the funding received by the scientific unit heavily dependent on the number of citations means that the dominant views will be promoted and will provide funds for further research for their authors. Meanwhile, dissenting points of view (no matter how well proven) will receive limited support or will be completely deprived of funds which will inhibit further research. As a result, the discourse in science may be limited, with a negative impact on the quality of research and the engagement of scientists in their work. Only the boldest or most prosperous may dare to use their slots on publications that may not achieve a sufficient number of citations.

The ways to approach science evaluation pursue a similar goal of a more efficient scientific research funding that ensures the development of science, society, and the economy. However, the means to achieve the goal are different: in the Republic of Croatia, a more individual approach is preferred, while in the Republic of Poland, a unified systemic solution was adopted. It is in both countries' best interest to closely monitor these consequences of these decisions and exchange observations. For science, reform is a process that is highly susceptible to external influences, which can drastically impair its effectiveness, as past experience has shown.

\section{REFERENCES}

1. Agency for Higher Education of Republic of Croatia (2021). Sustav visokog obrazovanja. Retrieved from https://www.azvo.hr/hr/visoko-obrazovanje/uloga-azvo-u-sustavu-visokogobrazovanja-i-znanosti-rh
2. Gadd, E. (2019). Influencing the changing world of research evaluation. Insights: The UKSG Journal, 32(1), 1-9. https://doi.org/10.1629/uksg.456

3. Geuna, A., \& Martin, B. R. (2003). University research evaluation and funding: An international comparison. Minerva, 41(4), 277-304. https://doi.org/10.1023/ B:MINE.0000005155.70870.bd

4. Government of Republic of Croatia. Odluka o programskom financiranju javnih visokih učilišta u Republici Hrvatskoj u akademskim godinama 2018./2019., 2019./2020., 2020./2021. i 2021./2022. (2018). Croatia. Retrieved from https://narodne-novine.nn.hr/clanci/sluzbeni/2018_09_87_1708.html

5. Knoth, P. (2016). Semantometrics, 235-236.

6. Korytkowski, P., \& Kulczycki, E. (2019). Publication counting methods for a national research evaluation exercise, Journal of Informetrics 13, 814

7. Kulczycki, E. (2019). Procedures of evaluation of basic units and institutions, Report VII, 9-12

8. Kulczycki, E., Korzeń, M., \& Korytkowski, P. (2017). Toward an excellence-based research funding system: Evidence from Poland, Journal of Informetrics 11, 295

9. Lewandowska, K., \& Kulczycki, E. (2021). Academic research evaluation in artistic disciplines: the case of Poland. Assessment and Evaluation in Higher Education, https:// doi.org/10.1080/02602938.2021.18936 51

10. Ministry of Science and Higher Education of Republic of Poland (2017). Statistical Statement of Results of Comprehensive Assessment of Scientific and Research and 


\title{
Journal of Contemporary Management Issues
}

Development Activities of Scientific Units - 2017, Retrieved from: https:// www.gov.pl/web/edukacja-i-nauka/ wyniki-kompleksowej-oceny-jakosci-dzialalnosci-naukowej-lub-badawczo-rozwojowej-jednostek-naukowych-2017

11. Molas-Gallart, J. (2015). Research evaluation and the assessment of public value. Arts and Humanities in Higher Education, 14(1), 111-126. https://doi. org/10.1177/1474022214534381

12. Ministry of Science and Education of Republic of Croatia (2019). Programsko financiranje visokih učilišta. Retrieved from https://mzo. gov.hr/UserDocsImages/dokumenti/ Vijesti/2019/2019/Programsko financiranje visokih učilišta.pdf

13. Ochsner, M., Kulczycki, E., Gedutis, A., \& Peruginelli, G. (2020). 2.3 National Research Evaluation Systems. In R. Ball (Ed.), Handbook of Bibliometrics (pp. 99-106).
De Gruyter Saur. https://doi.org/ doi:10.1515/9783110646610-011

14. Sima, K. (2017). Evidence in Czech research evaluation policy: Measured and contested. Evidence and Policy, 13(1), 81-95. https://doi.org/10.1332/174426 415X14467432784664

15. Thomas, D. A., Nedeva, M., Tirado, M. M., \& Jacob, M. (2020). Changing research on research evaluation: A critical literature review to revisit the agenda. Research Evaluation, 29(3), 275-288. https://doi.org/10.1093/ reseval/rvaa008

16. van den Besselaar, P., \& Sandström, U. (2020). Bibliometrically disciplined peer review: On using indicators in research evaluation. Scholarly Assessment Reports, 2(1). https://doi. org/10.29024/sar.16

17. Wagner, U. (2018). Digital transformation and challenges. Textile Network, 2018-May (5-6), 40-41.

\section{PREGLED ZNANSTVENE EVALUACIJE U POLJSKOJ I HRVATSKOJ}

\begin{abstract}
Sažetak
Znanost se smatra pokretačkom snagom društva i gospodarstva; stoga je, za postizanje navedenog, potrebna i odgovarajuća evaluacija, kao i alokacija financijskih sredstava. $U$ ovom se radu ukratko izlažu trendovi evaluacije znanstvenih aktivnosti u Poljskoj i Hrvatskoj. Na temelju pregleda literature, iskazuju se razlike u evaluacijskim sustavima navedenih zemalja, kao i nekoliko preporuka.
\end{abstract}

Ključne riječi: znanstvena evaluacija, poljski sustav znanstvene evaluacije, hrvatski sustav znanstvene evaluacije 